\title{
VIABILITAS RHIZOBIUM DALAM FORMULA BAHAN PEMBAWA DAN CARA INOKULASI DALAM TEKNIK PRODUKSI PUPUK HAYATI
}

\section{Jati Purwani $^{1 *}$ dan Didik Sucahyono ${ }^{2}$}

\author{
${ }^{1}$ Balai Penelitian Tanah \\ ${ }^{2}$ Balai Penelitian Tanaman Aneka Kacang dan Umbi \\ *E-mail: jati_purwani6243@yahoo.com
}

\begin{abstract}
ABSTRAK
Tanaman kedelai dapat memfiksasi nitrogen dengan bantuan bakteri bintil akar yaitu bakteri Rhizobium sp. Pemanfaatan Rhizobium sp sebagai inokulan pupuk hayati sangat mendukung peningkatan produktivitas kedelai. Inokulasi biji kedelai dengan Rhizobium sp dapat membantu penyediaan $\mathrm{N}$ tanah untuk kedelai. Formula pupuk hayati yang terdiri atas 6 konsorsia isolat Rhizobium sp telah diuji di beberapa lokasi pada tanah masam menunjukkan hasil yang positif. Penelitian teknik produksi pupuk hayati dilakukan di "Pilot Plant Produksi Pupuk Hayati" Balai Penelitian Tanah di Bogor. Penelitian disusun dengan rancangan acak lengkap, perlakuan terdiri atas kombinasi antara cara inokulasi dan pengemasan dengan formula bahan pembawa. Perlakuan terdiri atas delapan kombinasi perlakuan diulang tiga kali. Pertumbuhan bakteri Rhizobium sp sebelum diinokulasi ke dalam bahan pembawa diamati. Hasil penelitian menunjukkan bahwa isolat Rhizobium sp yang digunakan mempunyai fase pertumbuhan berkisar antara 4-48 jam. Populasi Rhizobium sp dalam formula pupuk hayati yang diinokulasi ke dalam bahan pembawa Biochar+Gambut (NI+BG) mampu mempertahankan populasi Rhizobium sp tertinggi hingga masa simpan 6 bulan dibandingkan perlakuan lainnya. Populasi Rhizobium sp pada perlakuan tersebut sebanyak 8,13 $\log$ CFU.g ${ }^{-1}$. Sedangkan populasi Rhizobium sp dalam pupuk hayati yang diinokulasikan menggunakan mesin injektor dengan bahan pembawa Biochar (IB) sebanyak 7,66 log CFU.g ${ }^{-1}$.
\end{abstract}

Kata kunci: bahan pembawa, teknik produksi, populasi, Rhizobium

\begin{abstract}
Soybean plants can fix nitrogen with the help of root nodules, namely the bacteria Rhizobium sp. The use of Rhizobium sp as a biological fertilizer inoculant greatly supports the increase in soybean productivity. Inoculation of soybean seeds with Rhizobium sp can help supply soil $N$ for soybeans. The bio-fertilizer formula consisting of 6 consortia of Rhizobium sp isolates has been tested in several locations on acid soils have positive results. Research on biofertilizer production techniques was carried out at the "Biofertilizer Pilot Plant" of the Soil Research Institute in Bogor. The study was arranged in a completely randomized design, the treatment consisted of the combination of inoculation and packaging methods with a carrier material formula. The treatment consisted of eight treatment combinations repeated three times. The growth of Rhizobium sp bacteria before being inoculated into the carrier was observed. The results showed that the Rhizobium sp isolates used had a growth phase ranging from 4-48 hours. The population of Rhizobium sp in the biological fertilizer formula inoculated into the carrier
\end{abstract}


material for Biochar + Peat $(N I+B G)$ was able to maintain the highest Rhizobium sp population up to life of 6 months compared to other treatments. The population of Rhizobium sp in this treatment was $8.13 \log$ CFU.g-1. While the population of Rhizobium sp at was inoculated using an injector machine with Biochar (IB) as the carrier material was $7.66 \log$ CFU.g-1.

Keywords: carrier material, production technique, population

\section{PENDAHULUAN}

Dalam mengembangkan pertanian berkelanjutan, perlu mempertimbangkan kesesuaian antara produksi, manfaat dan konservasi ekologi yaitu dengan mengurangi penggunaan bahan kimia seperti pupuk dan pestisida. Pemanfaatan pupuk hayati merupakan salah satu metode yang paling aman untuk membantu menyediakan unsur hara yang dibutuhkan tanaman serta berkontribusi dan berperan penting dalam meningkatkan kualitas tanaman serta mengurangi penggunaan pupuk kimia (Simanungkalit et al. 2006; Mohamed et al. 2016).

Aplikasi mikroba telah berkembang untuk keperluan industri, pertanian maupun lingkungan. Penggalian kemampuan mikroba yang bersifat menguntungkan di alam sangat penting karena mikroba merupakan harta kekayaan yang masih banyak tersembunyi dan tidak akan pernah habis untuk digali dan dikembangkan. Sebagian besar bakteri yang termasuk dalam pupuk hayati memiliki hubungan erat dengan akar tanaman. Rhizobium memiliki interaksi simbiosis dengan akar legum, sedangkan rhizobakteria hidup di permukaan akar atau di rhizosfer.

Untuk mencapai keberhasilan inokulasi maka Rhizobium atau rhizobacteria diperlukan populasi dalam jumlah yang besar. Jika populasinya tidak cukup besar, rhizobia/rhizobacteria asli akan menempati sebagian besar akar nodul/rhizosfer, menyebabkan efek inokulasi menjadi tidak optimal.

Dalam kebanyakan sistem pertanian, nitrogen paling sering merupakan nutrisi pembatas yang menentukan produksi tanaman. Meskipun keberadaannya di atmosfer dalam jumlah besar namun tanaman tidak dapat memanfaatkannya. Tanaman dapat memanfaatkan nitrogen dalam bentuk pupuk yang merupakan fiksasi kimia nitrogen atmosfer melalui proses Haber-Bosch. Proses ini membutuhkan tekanan dan tinggi suhu tinggi $\left(400-500^{\circ} \mathrm{C}\right)$ dan tekanan $20 \mathrm{MPa}$, setara dengan input energi sekitar 875 meter kubik gas alam, 5,5 barel minyak, atau 2 metrik ton batu bara untuk memfiksasi 1 metrik ton dari amonia. Banyak energi (945 kJ) diperlukan untuk memutus ikatan rangkap tiga ini dan di situlah letak salah satu tantangan utama fiksasi dinitrogen (Dixon and Wheeler. 1986).

Bakteri penambat nitrogen mampu memfiksasi $\mathrm{N}$ dari udara maupun di sekitar rhizofer tanaman, sehingga dapat meningkatkan ketersediaan pupuk $\mathrm{N}$ dalam tanah, mengurangi penggunaan pupuk $\mathrm{N}$ yang berasal dari pupuk. Asosiasi simbiotik adalah sumber alami terbesar dari $\mathrm{N}$ yang didaur ulang untuk mempertahankan sistem alami. Selain itu, bakteri fiksasi $\mathrm{N}$ oleh biji-bijian dan legum hijauan memainkan peran penting dalam memperkaya $\mathrm{N}$ tanah untuk memperbaiki tanaman non $\mathrm{N}_{2}$ yang selanjutnya ditanam sebagai bagian dari urutan atau rotasi tanam strategis (Iannetta et al., 2016).

Pemanfaatan pupuk hayati mikroorganisme dapat merangsang pertumbuhan tanaman (Kumar et al, 2001., Behl et al, 2003). Rhizobium sp adalah pupuk hayati pertama yang diproduksi komersial sebagai inokulan untuk berbagai tanaman legume (Kanaiyyan. 2002). Tanaman kedelai 
dapat memperoleh nitrogen dari dalam tanah apabila $\mathrm{N}$ cukup tersedia. Jika tidak, nitrogen dapat diperoleh dari udara dengan bantuan bakteri bintil akar yaitu bakteri Rhizobium sp yang hidup bersimbiosis dengan tanaman kacangkacangan. Untuk mendapatkan hasil yang tinggi dalam produksi kedelai. diperlukan inokulasi biji kedelai dengan Rhizobium sp. Mohamed et al. (2016), menemukan bahwa inokulasi multi-strain Rhizobium secara signifikan meningkatkan berat kering tunas, akar dan nodul dan jumlah nodul buncis. Pemanfaatan rhizobia sebagai inokulan pupuk hayati sangat mendukung upaya peningkatan produktivitas tanaman kacang-kacangan, khususnya kedelai. Keberhasilan aplikasi pupuk hayati sangat dipengaruhi oleh kualitas tanah dan mikroba yang digunakan yaitu berhubungan dengan kemampuan hidup dari mikroba inokulan dan kompetisinya dengan mikroba indigenous yang hidup dalam tanah. Selain karena tejadinya kompetisi antar mikroba, penambahan sisa-sisa tanaman (biomassa) sebagai sumber $\mathrm{C}$ ke dalam tanah juga akan mempengaruhi perkembangan populasi bakteri penambat N. Hal ini menjelaskan mengapa jumlah nitrogen yang ditambat oleh bakteri bervariasi pada tempat yang berbeda, tergantung pada ketersediaan energi dan kemampuan bakteri tersebut bersaing dengan mikroba indigenus yang hidupnya tergantung dari sumber energi yang sama.

Beberapa peneliti telah menunjukkan bahwa kinerja produk formulasi rhizobia dengan bahan pembawa gambut sebanding dengan formulasi dalam media cair YEMB (Yeast Ekstrak Mannitol Broth). Hasil uji coba yang dilakukan oleh Brahmaprakash et al. (2007) menunjukkan bahwa inokulasi Rhizobium dengan media cair maupun dengan bahan pembawa meningkatkan hasil kacangkacangan (kacang tanah, kacang gude, buncis dan kedelai) dibandingkan tanpa inokulasi, peningkatan hasil sebesar 10$30 \%$ dibandingkan dengan tanpa inokulasi, Produksi kacang-kacangan lebih tinggi dengan inokulan cair dibandingkan inokulan dengan bahan pembawa padat. Dalam hal produksi skala besar penggunaan media cair YEMB tentu saja memerlukan biaya yang lebih tinggi dalam pengangkutan dibandingkan apabila diganti dengan bahan pembawa lain seperti gambut, arang sekam dan lainnya. Dalam hal ini arah penelitian ditujukan agar pupuk hayati dapat disimpan dalam jangka lama agar dapat diproduksi secara massal.

Bahan pembawa yang cocok berperan penting dalam mentransfer mikroorganisme hidup ke rhizosfer, inokulan yang berkualitas baik harus dibuat dari bahan pembawa yang unggul. Berbagai jenis bahan dapat digunakan sebagai pembawa untuk inokulasi benih atau tanah. Untuk persiapan benih inokulan, bahan pembawa digiling menjadi bubuk halus dengan ukuran partikel 10-40 $\mu \mathrm{m}$.

Karakter bahan pembawa berkualitas unggul untuk inokulan mikroba adalah kapasitas dalam menampung dan retensi air yang baik, tidak panas dengan adanya pembasahan, sifat fisik dan kimia seragam, tidak beracun untuk bakteri strain inokulan, mudah terurai secara hayati dan tidak berpolusi, $\mathrm{pH}$ hampir netral atau mudah disesuaikan, mendukung pertumbuhan dan ketahanan bakteri, melepaskan cepat bakteri di tanah, mudah diproses dan bebas dari bahan pembentuk gumpalan, mudah disterilkan dengan autoklaf atau iradiasi gamma, tersedia dalam jumlah yang memadai serta murah, daya rekat yang baik pada biji, kapasitas buffer yang baik (Smith. 1992, Somasegaran dan Hoben, 1994).

Keterbatasan bahan pembawa pupuk hayati dari gambut mendorong peneliti untuk mencari bahan pembawa pengganti yang mudah tersedia, murah, mampu mempertahankan populasi mikrobia. Elsafi dan Husen (1991) telah menguji dengan menggunakan bahan pembawa arang dan lumpur saring, kedua pembawa 
ditemukan cocok dan mempertahankan populasi rhizobia yang tinggi $\left(1,0 \times 10^{8}\right.$ CFU.g $\left.{ }^{-1}\right)$. Bubuk arang juga telah diuji oleh Osman dan Mohammed (2002). Pemanfaatan lumpur Nil sebagai bahan pembawa telah dilakukan oleh (Elgali $e t$ al. 2002; Osman dan Mohammed. 2002; Abdelrahim. 2005) menggunakan lumpur Nil, ampas tebu, kulit kacang tanah dan bubuk arang sebagai pembawa rhizobia. Semua zat yang diuji terbukti efisien, tetapi arang ditemukan lebih unggul dalam hal jumlah mempertahankan jumlah populasi rhizobia. Selain itu arang juga lebih unggul dalam hal ketersediaan dan kelimpahan serta kapasitas penampung airnya yang tinggi, kontaminasi rendah, dan kewajiban kontaminasi dan kemampuan penyimpanan selama 60 hari pada suhu kamar.

Pupuk hayati berbasis Rhizobium merupakan salah pupuk hayati kedelai yang dihasilkan oleh Balai Penelitian Tanaman Kacang dan Ubi (Balitkabi) Badan Litbang Pertanian, dan telah diuji pada berbagai lokasi (Provinsi Banten, Lampung, Kalimantan Selatan, Jambi) dan menunjukkan hasil yang positif. Dalam rangka mendukung peningkatan produktivitas kedelai, maka pengembangan produksi pupuk hayati tersebut dalam skala massal perlu dilakukan. Pupuk hayati yang efektif selain dapat meningkatkan produksi juga dapat mengefisienkan pemakaian pupuk kimia, mendukung bagi terciptanya sistem pertanian ramah lingkungan dan berkelanjutan. Penelitian ini bertujuan untuk mengetahui teknik terbaik pada produksi sel Rhizobium yang dilakukan pada skala pilot $(10 \mathrm{~L})$ yang selanjutnya dikemas dengan bahan pembawa padat. Parameter-parameter yang digunakan antara lain waktu penyimpanan dan viabilitas sel formula pupuk hayati berbasis Rhizobium dalam penyimpanan yang memenuhi standar mutu yang telah ditetapkan oleh Peraturan Menteri Pertanian Nomor 261 tahun 2019 tentang Persyaratan Teknis Minimal Pupuk
Organik, Pupuk Hayati, dan Pembenah Tanah.

\section{METODE}

Produksi dimulai dengan kultur agar miring murni isolat Rhizobium, selanjutnya diinokulasikan ke dalam larutan sari khamir mannitol (SKM) dalam Erlenmeyer untuk digunakan sebagai kultur starter yang akan digunakan untuk memproduksi rhizobia dalam jumlah besar di dalam sebuah fermentor yang terbuat dari logam dengan kapasitas fermentor 10-15 L. Kultur starter 1 L diperlukan untuk menginokulasi $100 \mathrm{~L}$ media di dalam fermentor (Somasegaran dan Hoben, 1994). Dalam usaha pengembangan untuk industri skala besar, maka diperlukan informasi bioproduk pupuk hayati berbasis Rhizobium pada skala pilot yang dapat diaplikasikan dalam industri skala besar. Hal ini memerlukan scaling up dari jumlah kecil produk biologi yang diproduksi di laboratorium kemudian dikembangkan ke dalam proses dengan volume lebih besar (scale up).

\section{Pembuatan Starter dan Propagasi Kultur}

Inokulan stok bakteri Rhizobium pada agar miring (KDL176, KDL92A, KDL92B, KDL196, KDL182, KDL92), diremajakan kembali agar diperoleh selsel vegetatif yang aktif, selanjutnya dipropagasi lebih dahulu, yaitu dengan menginokulasikan sebanyak 1 ose sel vegetatif ke dalam $100 \mathrm{~mL}$ dalam media YEMB (Yeast Extract Mannitol Broth), kemudian dishaker pada rotary shaker untuk mempersiapkan kultur starter selama 2 hari.

Selanjutnya inokulum starter dari isolate Rhizobium yang siap di inokulasikan ke dalam fermentor disebut dengan starter (biakan aktif). Starter diinokulasikan ke dalam fermentor yang sudah mengandung media perbanyakan yang sudah steril. Media dalam fermentor 
terdiri atas kentang dan glukosa yang diperkaya dengan bahan lainnya. Kultur starter Rhizobium diinokulasikan ke dalam fermentor (kapasitas 10 L) masing-masing sebanyak $100 \mathrm{~mL}$, mikroba dalam fermentor ditumbuhkan selama 2 hari. Untuk mengetahui perkembangan bakteri dalam fermentor, maka dilakukan pengamatan pada 4,8 , 24, 32, dan 48 jam.

\section{Pertumbuhan Rhizobium pada berbagai bahan pembawa dan cara inokulasi}

Penelitian dirancang dengan rancangan acak lengkap yang terdiri atas delapan perlakuan dengan tiga ulangan, dengan perlakuan sebagai berikut:

1. Inokulan disuntikkan ke dalam bahan pembawa Biochar steril dalam kemasan plastik (IB)

2. Inokulan disuntikkan ke dalam bahan pembawa steril (Biochar + Fosfat alam) dalam kemasan plastik (I-BF)

3. Inokulan disuntikkan ke dalam bahan pembawa steril (Biochar + Gambut) dalam kemasan plastik (I-BG)

4. Inokulan disuntikkan ke dalam bahan pembawa steril (Biochar + Gambut + Fosfat alam) dalam kemasan plastik (I-BGF)

6. 5 (lima) inokulan dicampur ke dalam bahan pembawa steril Biochar, setelah tercampur rata dikemas menggunakan mesin pengemas (NI-B) Inokulan dicampur ke dalam bahan pembawa steril Biochar+Fosfat Alam, setelah tercampur rata dikemas menggunakan mesin pengemas (NI-BF)

7. Inokulan dicampur ke dalam bahan pembawa steril (Biochar + Gambut) setelah tercampur rata dikemas menggunakan mesin pengemas (NI$\mathrm{BG})$
8. Inokulan dicampur ke dalam bahan pembawa steril Biochar + gambut + Fosfat Alam, setelah tercampur rata dikemas menggunakan mesin pengemas (NI-BGF)

Bahan pembawa yang akan diinokulasi dengan cara disuntikkan dikemas dalam kemasan $40 \mathrm{~g} / \mathrm{sachet}$ (Gambar 1) selanjutnya disterilisasi dengan autoclave. Setelah bahan pembawa disterilkan, selanjutnya inokulan sebanyak $10 \mathrm{~mL}$ dimasukkan ke dalam bahan pembawa dengan cara menyuntikkan ke dalam bahan pembawa yang sudah dimasukkan ke dalam kantong plastik, selain itu juga dilakukan pengemasan bahan pembawa dengan menggunakan alat pengemas (Gambar 2). Sedangkan inokulasi tidak dengan cara penyuntikan, namun bahan pembawa yang sudah disteril terlebih dahulu diinokulasi mikroba dengan cara dicampurkan, setelah inokulan mikroba tercampur homogen selanjutnya dikemas kedalam dalam kantong plastik dengan menggunakan mesin pengemas. Bobot pupuk hayati dalam kemasan baik dengan cara inokulasi kedalam bahan pembawa steril yang sudah dikemas maupun dengan bahan pembawa steril belum dikemas dan dikemas dengan menggunakan mesin pengemas mempunyai bobot yang sama, kurang lebih $50 \mathrm{~g} / \mathrm{sachet}$.

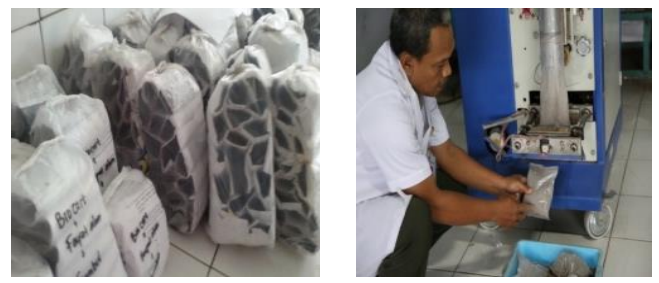

Gambar 1. Pengemasan inokulan

Inokulan yang sudah diinokulasikan ke dalam bahan pembawa selanjutnya diinkubasi dalam suhu ruang, Pengamatan populasi dilakukan hingga viabilitas mikroba dalam masa penyimpanan sudah mulai menurun dan sudah tidak memenuhi standar. 


\section{HASIL DAN PEMBAHASAN}

\section{Pertumbuhan Rhizobium}

Berdasarkan Gambar 2, dapat diketahui bahwa pertumbuhan Rhizobium isolat KDL 176, pada 2 jam setelah inokulasi menunjukkan populasi sebesar 9,25 $\log \mathrm{cfu} / \mathrm{ml}$, mencapai pertumbuhan maksimum yaitu pada waktu $24 \mathrm{jam}$ sebesar 12,71 log cfu/ml. dan pada masa akhir saat panen jumlah populasi isolat KDL 176 mengalami penurunan menjadi 11,49 log $\mathrm{cfu} / \mathrm{ml}$. Pada Gambar 3, tampak bahwa populasi isolat KDL 92A pada 2 jam setelah inokulasi yaitu sebesar 10,01 log cfu/ml.

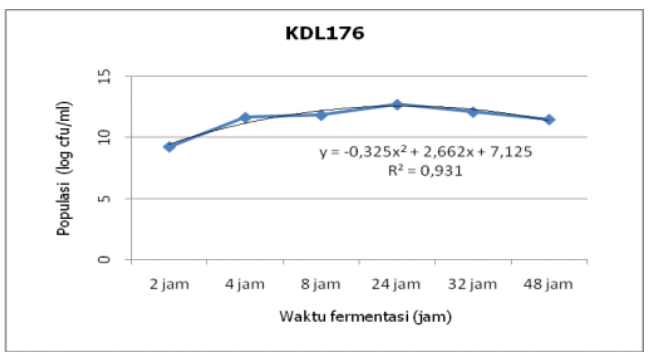

Gambar 2. Populasi Rhizobium isolat KDL 176 dalam produksi batch cair pada berbagai waktu pengamatan

Pertumbuhan maksimum populasi isolat KDL 92A pada waktu 8 jam setelah inokulasi sebesar 11,98 $\log \mathrm{cfu} / \mathrm{ml}$ dan pada 48 jam setelah inokulasi populasi isolat $\mathrm{KDL} 92 \mathrm{~A}$ sebesar 10,72 log $\mathrm{cfu} / \mathrm{ml}$.

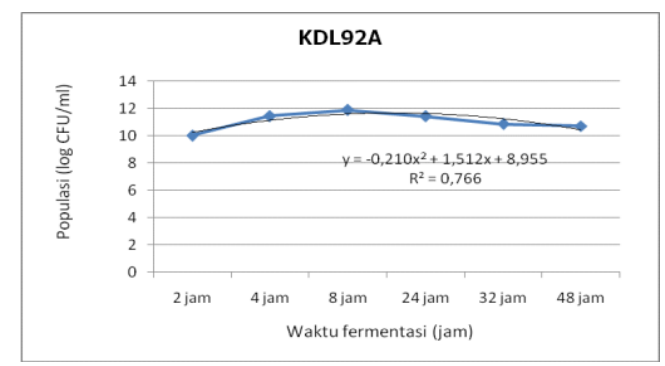

Gambar 3. Populasi Rhizobium isolat KDL92A dalam produksi batch cair pada berbagai waktu pengamatan

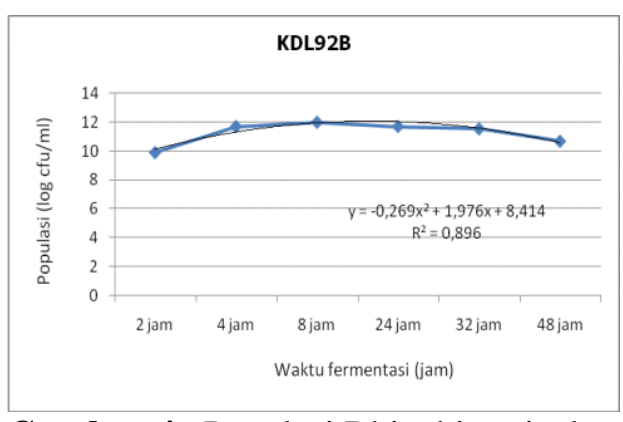

Gambar 4. Populasi Rhizobium isolate KDL 92 B dalam produksi batch cair pada berbagai waktu pengamatan

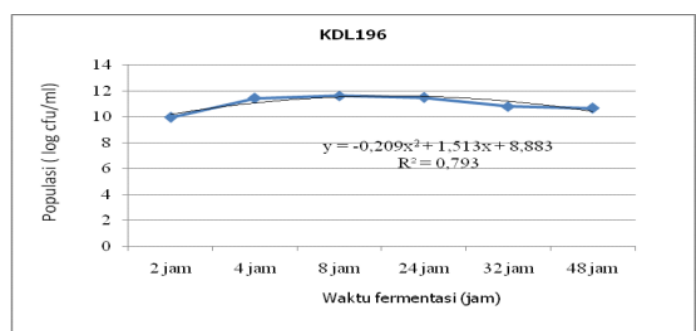

Gambar 5. Populasi Rhizobium isolat KDL 196 dalam produksi batch cair pada berbagai waktu pengamatan

Pada pertumbuhan isolat KDL $92 \mathrm{~B}$, jumlah populasi Rhizobium isolat KDL 92B pada 0 jam pengamatan diketahui sebesar 9,89 log cfu/ml. Isolat KDL 92B mengalami pertumbuhan maksimum pada waktu 8 jam sebesar 11,98 log cfu/ml. pada waktu 24 jam hingga 48 jam mengalami penurunan jumlah populasi $\mathrm{u}$ menjadi 10,67 log cfu/ml (Gambar 4).

Pertumbuhan isolat KDL196 pada 0 jam yaitu sebesar 9,94 log $\mathrm{cfu} / \mathrm{ml}$ mengalami kenaikan hingga pertumbuhan maksimum pada waktu 24 jam sebesar 11,80 cfu/ml. Dan saat dipanen waktu 48 jam populasi isolat KDL 196 sebesar $10.86 \quad \log \mathrm{cfu} / \mathrm{ml}$ (Gambar 7). Pada Gambar 8 tampak bahwa grafik populasi pertumbuhan isolat KDL 182 pada saat 0 jam atau waktu awal inokulasi sebesar 10,11 log $\mathrm{cfu} / \mathrm{ml}$. Isolat tersebut mengalami pertumbuhan maksimum pada waktu 4 jam yaitu sebesar 12,69 log cfu/ml, mengalami penurunan hingga saat waktu pengamatan 24 jam. 


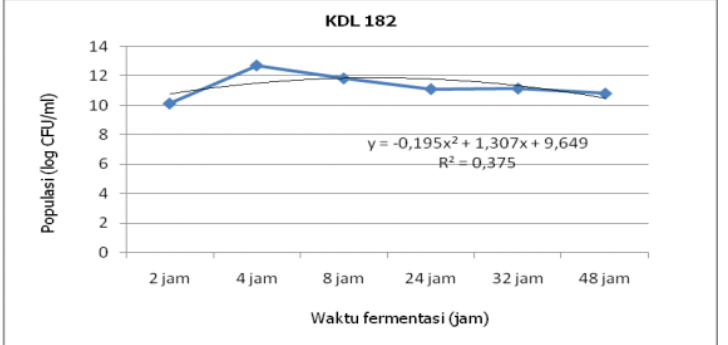

Gambar 6. Pertumbuhan isolat bakteri Rhizobium (KDL 182) dalam produksi batch cair pada berbagai waktu pengamatan

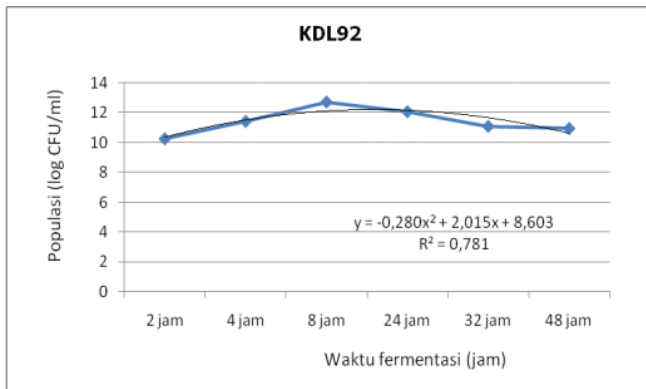

Gambar 7. Pertumbuhan isolate bakteri Rhizobium (KDL 92) dalam produksi batch cair pada berbagai waktu pengamatan
Isolat bakteri Rhizobium (KDL 92), pada 2 jam setelah inkubasi menunjukkan populasi sebanyak 10,24 log $\mathrm{cfu} / \mathrm{ml}$, mengalami pertumbuhan jumlah populasi maksimum pada waktu 24 jam sebesar $12,71 \log \mathrm{cfu} / \mathrm{ml}$. Pada 48 jam setelah inkubasi jumlah populasi isolat KDL92 mengalami penurunan, namun jika dibandingkan ketika 2 jam masih lebih tinggi, populasi saat 2 jam setelah inkubasi sebanyak 10,93 log $\mathrm{cfu} / \mathrm{ml}$. Pertumbuhan maksimun isolat yang digunakan untuk formula pupuk berbasis bakteri Rhizobium menunjukkan pertumbuhan maksimum pada 4 jam.

Pengamatan populasi mikroba pupuk hayati berbasis Rhizobium pada berbagai bahan pembawa selama masa penyimpanan

Bakteri Rhizobium sp yang diformulasikan dengan berbagai formula bahan pembawa pada berbagai masa penyimpanan menunjukkan mempunyai viabilitas tinggi (populasi mikroba $>10^{7}$ cfu. $\mathrm{g}^{-1}$ ) hingga masa simpan 6 bulan pada beberapa formula bahan pembawa.

Tabel 1. Populasi isolat bakteri Rhizobium pada berbagai jenis bahan pembawa padat dan cara inokulasi pada berbagai umur penyimpanan

\begin{tabular}{lccccc}
\hline \multirow{2}{*}{ Perlakuan } & \multicolumn{5}{c}{ Masa Simpan (Bulan) } \\
\cline { 2 - 6 } & 2 & 3 & 4 & 5 & 6 \\
\hline I-B & $12,97 \mathrm{~b}$ & $8,35 \mathrm{a}$ & $8,16 \mathrm{a}$ & $7,74 \mathrm{c}$ & $7,66 \mathrm{~b}$ \\
NI-B & $13,83 \mathrm{c}$ & $13,58 \mathrm{c}$ & $12,46 \mathrm{~b}$ & $6,87 \mathrm{~b}$ & $6,73 \mathrm{~b}$ \\
I-BF & $11,91 \mathrm{a}$ & $13,31 \mathrm{c}$ & $7,97 \mathrm{a}$ & $7,88 \mathrm{c}$ & $7,08 \mathrm{~b}$ \\
NI-BF & $13,37 \mathrm{bc}$ & $13,31 \mathrm{c}$ & $8.73 \mathrm{a}$ & $4,29 \mathrm{a}$ & $4,12 \mathrm{a}$ \\
I-BG & $13,44 \mathrm{bc}$ & $10,31 \mathrm{~b}$ & $8,53 \mathrm{a}$ & $9,19 \mathrm{c}$ & $7,19 \mathrm{~b}$ \\
NI-BG & $13,44 \mathrm{bc}$ & $10,19 \mathrm{~b}$ & $9,13 \mathrm{a}$ & $8,75 \mathrm{c}$ & $8,13 \mathrm{c}$ \\
I-BGF & $13,13 \mathrm{~b}$ & $11,03 \mathrm{~b}$ & $8.81 \mathrm{a}$ & $7,19 \mathrm{bc}$ & $7,09 \mathrm{~b}$ \\
NI-BGF & $12,99 \mathrm{~b}$ & $12,34 \mathrm{c}$ & $8,28 \mathrm{a}$ & $5,65 \mathrm{a}$ & $5,37 \mathrm{a}$ \\
\hline
\end{tabular}

Keterangan: Angka-angka pada kolom yang sama dan diikuti oleh huruf yang sama menunjukkan tidak berbeda nyata 5\% DMRT. I (Injeksi), NI (Non Injeksi), B (Biochar), G (gambut), F (Fosfat Alam)

Berbagai cara inokulasi ke dalam bahan pembawa yang dicobakan yaitu dengan cara injeksi dan non injeksi. Populasi bakteri pada cara non injeksi dengan bahan pembawa biochar (arang sekam), biochar+fosfat alam, biochar+ gambut dan biochar+gambut+fosfat alam menunjukkan populasi mikroba lebih tinggi dibandingkan dengan cara injeksi. Namun demikian untuk mendapatkan masa penyimpanan pupuk hayati yang lebih lama, maka perlakuan inokulasi dengan cara injeksi akan lebih baik, hal ini terbukti dengan cara inokulasi melalui 
injeksi, maka mikroba dapat bertahan hidup lebih lama pada semua formula bahan pembawa (Tabel 1).

\section{KESIMPULAN}

1. Isolat bakteri Rhizobium yang digunakan mempunyai fase pertumbuhan maksimum, berkisar antara 4-48 jam

2. Inokulasi mikroba pupuk hayati ke dalam bahan pembawa yang sudah dikemas dalam plastik sachet dan sudah steril mampu memberikan viabilitas yang masih tinggi dengan populasi Rhizobium > 7,0 log cfu. $\mathrm{g}^{-1}$ pada berbagai formula bahan pembawa sampai masa simpan 6 bulan.

3. Populasi Rhizobium dalam pupuk hayati yang diinokulasi kedalam bahan pembawa steril lebih dahulu kemudian dikemas menggunakan mesin packaging dengan bahan pembawa biochar+gambut pada masa penyimpanan 6 bulan viabilitas populasi bakteri Rhizobium tertinggi yaitu sebanyak $8,13 \log$ cfu. $\mathrm{g}^{-1}$,

\section{DAFTAR PUSTAKA}

Asie ER. 2005. Nodulasi dan Hasil Kedelai Akibat pemberian Pupuk Hayati dan Bahan Organik Berbeda Waktu Pengomposan. Agrivita. 27 (1): 7-13

Bashan Y and Holguin G. 1997. Azospirillum - Plant Relationship Environmental and Physiological Advances. Can. J. Microbiol. 43:103121.

Bashan Y. 1998. Inoculants of plant growth-promoting bacteria for use in Agriculture. Biotechnol Adv 16:729770

Behl RK, Sharma H, Kumar V and Narula N," Interactions amongst mycorhiza, Azotobacter Chroococcum and root characteristics of wheat varieties" J. Argon. Crop Sci. Vol 189, 2003, pp 151-155.
Bhattacharyya P, Singh T (1992). Simplified methods of mass production and application of biofertilizer. Proc. Natl. Sem. Organic farming. Edited by Rai MM, Verma LN, JNKVV and IGKVV, Indore, India, pp. 166-178.

Brahmaprakash, G.P.; Girisha, H.C.; Vithal Navi.; Laxmipathy, R.; Hegde, S.V.: 'Liquid Rhizobium inoculant formulations to enhance biological nitrogen fixation in food legumes. Journal of Food Legumes. 20, pp. 75 $79,(2007)$

ISI (1986). Indian standard specification for Rhizobium inoculants. Standard: IS 8268-1986.

Jauhari KS (1988). Dilution optima of broth cultures for maximizing production of carrier based inoculants. Curr. Sci. 57: 507-509. Jauhari KS, Subba Rao NS (1984) Simple glass fermentor for Rhizobium culture production. Curr. Sci. 53: 984-985.

Kannaiyan S, "Biofertilizers for sustainable crop production..In: Kannaiyan. S (ed) Biotechnology and biofertilizers"Kluwer Academic Publishers, Derdrecht, The Netherlands, 2002, pp 9-49

Kementerian Pertanian 2010. Rencana Strategis Kementerian Pertanian Tahun 2010-2014.

Kumar V, Behl RK and Narula N ," Establishment of phosphate solubilising strains of Azotobacter chroococcum in the rhizosphere and their effect on wheat cultivars under greenhouse conditions," Microbiol. Res.vol 156, 2001, pp 87-93.

Mishra BK, Dadhich SK (2010). Methodology of nitrogen biofertilizer production. J. Adv. Dev. Res. 1: 3-6.

Mohamed ASA, Adel Kamal Khider AKA and Sekaran M. 2016. Effect of storage Temperature, Duration and Types of Biofertilizer Carriers on Survival and Numbers of Bacterial Strains Bacillus megaterium var. phosphaticum, Azotobacter chroococcum, Rhizobium leguminosarum and Transformant, 
Transconjugant $B$. megaterium var. phosphaticum

Simanungkalit RDM, D.A. Suriadikarta, R. Saraswati, D. Setyorini, dan W. Hartatik, Pupuk Organik dan Pupuk Hayati. Bogor: Balai Besar Penelitian dan Pengembangan Sumberdaya Lahan Pertanian (2006).

Simarmata TR. Hindersah. 1999. Optimalisasi Aplikasi Pupuk Biologis untuk Meningkatkan Produktivitas Lahan Menuju Pertanian Berkelanjutan. Prosiding Kongres Nasional VII HITI, Bandung. p 729736.

Smith RS. 1992. Legume inoculant formulation and application'. Canadian Journal of Microbiology. 38, pp. 485-492.
Somasegaran P, Hoben HJ (1985). Methods in legume Rhizobium technology. NifTAL, MIRCEN, Univ. Hawaii, Paia, USA, p. 367

Somasegaran, P. and H.J. Hoben. 1994. Handbook for Rhizobia. SpringerVerlag, New York.

Sulistyowati CA (2002). Can Organic Agriculture Help Farmers? The Jakarta Post, Monday September 30, p.7.

Xavier I.J, Holloway G, Leggett M. 2004. Dvelopment of Rhizobial inoculants formu-lation. Doi: 101094/CM-2004-0301-06-RV. http: www.plantmanagent net work.org/pub/m/review /2004/ develop/.Accessed 17 Maret 2013. 
Jurnal Agrosains dan Teknologi Volume 5 No. 2 Desember 2020 website : jurnal.umj.ac.id/index.php/ftan
p-ISSN 2528-0201

e-ISSN 2528-3278 